\title{
A Novel Periplasmic Protein, VrpA, Contributes to Efficient Protein Secretion by the Type III Secretion System in Xanthomonas spp.
}

\author{
Xiaofeng Zhou, ${ }^{1}$ Xiufang Hu, ${ }^{1,2}$ Jinyun $\mathrm{Li}^{1}{ }^{1}$ and Nian Wang ${ }^{1}$ \\ ${ }^{1}$ Department of Microbiology and Cell Science, Citrus Research and Education Center, University of Florida, Lake Alfred \\ 33850, U.S.A.; ${ }^{2}$ College of Life Science, Zhejiang Sci-Tech University, Road 2, Xiasha, Hangzhou, 310018, China
}

Submitted 6 October 2014. Accepted 15 October 2014.

Efficient secretion of type III effector proteins from the bacterial cytoplasm to host cell cytosol via a type III secretion system (T3SS) is crucial for virulence of plant-pathogenic bacterium. Our previous study revealed a conserved hypothetical protein, virulence-related periplasm protein $\mathrm{A}$ (VrpA), which was identified as a critical virulence factor for Xanthomonas citri subsp. citri. In this study, we demonstrate that mutation of $v r p A$ compromises $X$. citri subsp. citri virulence and hypersensitive response induction. This deficiency is also observed in the $X$. campestris pv. campestris strain, suggesting a functional conservation of VrpA in Xanthomonas spp. Our study indicates that $\operatorname{VrpA}$ is required for efficient protein secretion via $\mathrm{T3SS}$, which is supported by multiple lines of evidence. A $\mathrm{CyaA}$ reporter assay shows that VrpA is involved in type III effector secretion; quantitative reverse-transcription polymerase chain reaction analysis suggests that the $v r p A$ mutant fails to activate citrus-canker-susceptible gene $C s L O B 1$, which is transcriptionally activated by transcription activator-like effector PthA4; in vitro secretion study reveals that VrpA plays an important role in secretion of T3SS pilus, translocon, and effector proteins. Our data also indicate that VrpA in $X$. citri subsp. citri localizes to bacterial periplasmic space and the periplasmic localization is required for full function of $\operatorname{VrpA}$ and $X$. citri subsp. citri virulence. Protein-protein interaction studies show that VrpA physically interacts with periplasmic T3SS components HrcJ and HrcC. However, the mutation of VrpA does not affect T3SS gene expression. Additionally, $\operatorname{VrpA}$ is involved in $X$. citri subsp. citri tolerance of oxidative stress. Our data contribute to the mechanical understanding of an important periplasmic protein VrpA in Xanthomonas spp.

The type III secretion system (T3SS) and T3SS effectors (T3Es) are critical for pathogenicity of many important pathogenic bacteria, including animal pathogens (e.g., Yersinia and Salmonella spp., Escherichia coli, and Shigella spp.) and plant pathogens (e.g., Xanthomonas, Ralstonia, and Pseudomonas spp.) (Bliska et al. 2013; Diepold and Wagner 2014; Feng and Zhou 2012; Tampakaki et al. 2010). The T3SS apparatus of

Corresponding author: N. Wang; E-mail: nianwang@ufl.edu

* The $e$-Xtra logo stands for "electronic extra" and indicates that nine supplementary figures and two supplementary tables are published online.

(C) 2015 The American Phytopathological Society animal pathogens typically forms needle structures (Fujii et al. 2012); however, the plant pathogen T3SS apparatus forms syringae structures (Lohou et al. 2013) to inject T3Es into host cells. T3SS in plant-pathogenic bacteria is encoded by hypersensitive reaction and pathogenicity ( $h r p$ ) and $h r p$ conserved (hrc) genes (Bogdanove et al. 1996). A typical T3SS consists of an extracellular nanopilus with a translocon, an inner membrane (IM), an outer membrane (OM) ring structure connected with a periplasmic rod, and a predicted cytoplasmic ring structure (Büttner 2012). Comparative sequence analyses indicate that at least 9 of more than 20 T3SS components are conserved among plant- and animal-pathogenic bacteria. The conserved T3SS components are likely the core components of the secretion apparatus in the IM and OM (Büttner 2012).

Due to the importance of T3SS and T3Es, dramatic progress has been made in understanding T3SS gene regulation, the T3SS apparatus assembly and architecture, and effector secretion. The assembly process is largely controlled by the T3SS gene cluster. It is assumed that T3SS assembles through a hierarchical process, wherein the extracellular components of the machinery are secreted prior to effectors, the ring structures in the IM and OM are assembled before the inner rod (Sukhan et al. 2001), and the export apparatus is assembled before the needle complex forms (Wagner et al. 2009).

Because the T3SS spans the membrane, periplasmic components have been shown to affect the T3SS through multiple mechanisms. For example, one study showed that peptidoglycan binds to $\operatorname{HrpB} 1$, which is a periplasmic component of T3SS and binds to T3S system components, including the inner membrane protein $\mathrm{HrcD}$, the secretin $\mathrm{HrcC}$, the pilus protein HrpE, and the putative inner rod protein HrpB2 (Hausner et al. 2013). Studies have shown that periplasmic lytic transglycosylases are required for efficient T3SS assembly because the natural pores of peptidoglycan are too narrow for T3SS apparatus formation (Garcia-Gomez et al. 2011; Zahrl et al. 2005). The lytic transglycosylases cleave the $\beta$-1,4-glycosidic bond between $\mathrm{N}$-acetylglucosamine and $\mathrm{N}$-acetylmuramic acid in the peptidoglycan during T3SS apparatus formation. CtpA is a soluble periplasmic carboxyl-terminal-processing protease protein. CtpA is essential for normal T3SS function in Pseudomonas aeruginosa, cytotoxicity toward the host cells, and virulence in a mouse model of acute pneumonia. It was suggested that CtpA activity might be required for proper T3SS assembly or function, even though experimental evidence is lacking (Seo and Darwin 2013). MreC, which is a periplasmic cytoskeletal element that controls cell shape in Salmonella spp., has also been reported to affect T3SS. The cytoskeleton is dispensable to T3SS structure assembly but is essential for Salmonella 
pathogenicity island-1 type (SPI-1) T3SS gene expression. The regulation is mediated by the two-component system sensor kinase $\mathrm{RcsC}$, which detects changes at the cell surface caused by bacterial cytoskeleton disintegration (Bulmer et al. 2012).

In addition to periplasmic proteins, a potential link between outer-membrane protein (OMP) assembly and T3SS gene expression was suggested (Amy et al. 2004; Fardini et al. 2007). Mutation of bamB, which encodes a lipoprotein involved in OMP assembly, downregulated expression of SPI-1, SPI-2, and flagella genes as well as impaired the ability of Salmonella cells to invade epithelial cells and secrete T3SS-1 effectors and flagellar proteins (Amy et al. 2004; Fardini et al. 2007). Both the T3SS and flagella are membrane-spanning apparatuses and share high identity in many components (Kawamoto et al. 2013). Soscia and colleagues (2007) showed that T3SS and flagellar assembly exhibit negative cross-control. A $P$. aeruginosa strain without flagella showed increased T3SS gene expression, effector secretion, and cytotoxicity (Soscia et al. 2007). Interestingly, DsbA, which is a periplasmic disulfide-bonded oxidase, affects SPI-1 regulation and SPI-1 function through a feedback inhibition of SPI-1 transcription in Salmonella spp. (Lin et al. 2008). This inhibition depends on the flagellar protein FliZ and RcsCDB phosphorelay system (Majdalani and Gottesman 2005). Overall, previous studies suggest that the T3SS is affected by multiple factors at the cell wall.

In this study, we reported one novel hypothetical periplasmic protein, XAC3049, which is designated as virulence-related periplasmic protein A (VrpA), and revealed that the secretion of T3SS proteins and T3Es are affected in Xanthomonas citri subsp. citri. $X$. citri subsp. citri is a gram-negative aerobic bacterium that causes citrus canker, which is one of the most devastating diseases for most commercial citrus cultivars and is responsible for significant economic losses worldwide (Gottwald and Riley 2005). Xanthomonas spp. are an important group of plant-pathogenic bacteria that infect a wide range of hosts, including at least 68 plant families and more than 240 genera, as well as many economically important crops such as rice, citrus, banana, cabbage, tomato, pepper, and bean (Ryan et al. 2011). Previous studies from our laboratory showed that an XAC3049 EZ-Tn5 insertion mutant did not produce visible citrus canker symptoms on grapefruit (Yan and Wang 2012). In this study, we further studied the localization of VrpA, its effect on secretion of extracellular components of T3SS and T3Es, its interactions with T3SS components, and its homologs in other xanthomonads.

\section{RESULTS}

\section{VrpA contributes to $X$. citri subsp. citri virulence in citrus plant and hypersensitive response induction in nonhost tobacco.}

A previous study from our laboratory showed that an EZTn5 insertion mutant, 416G9, produced no visible citrus canker symptoms on grapefruit (Yan and Wang 2012). The vrpA open reading frame (ORF) (XAC3049) was inserted by EZTn5 in both 416G9 and 329E2 mutants (Yan and Wang 2012) (Fig. 1A). To confirm whether $v r p A$ is involved in $X$. citri subsp. citri virulence, the $v r p A$ deletion mutant was generated through

\section{A}
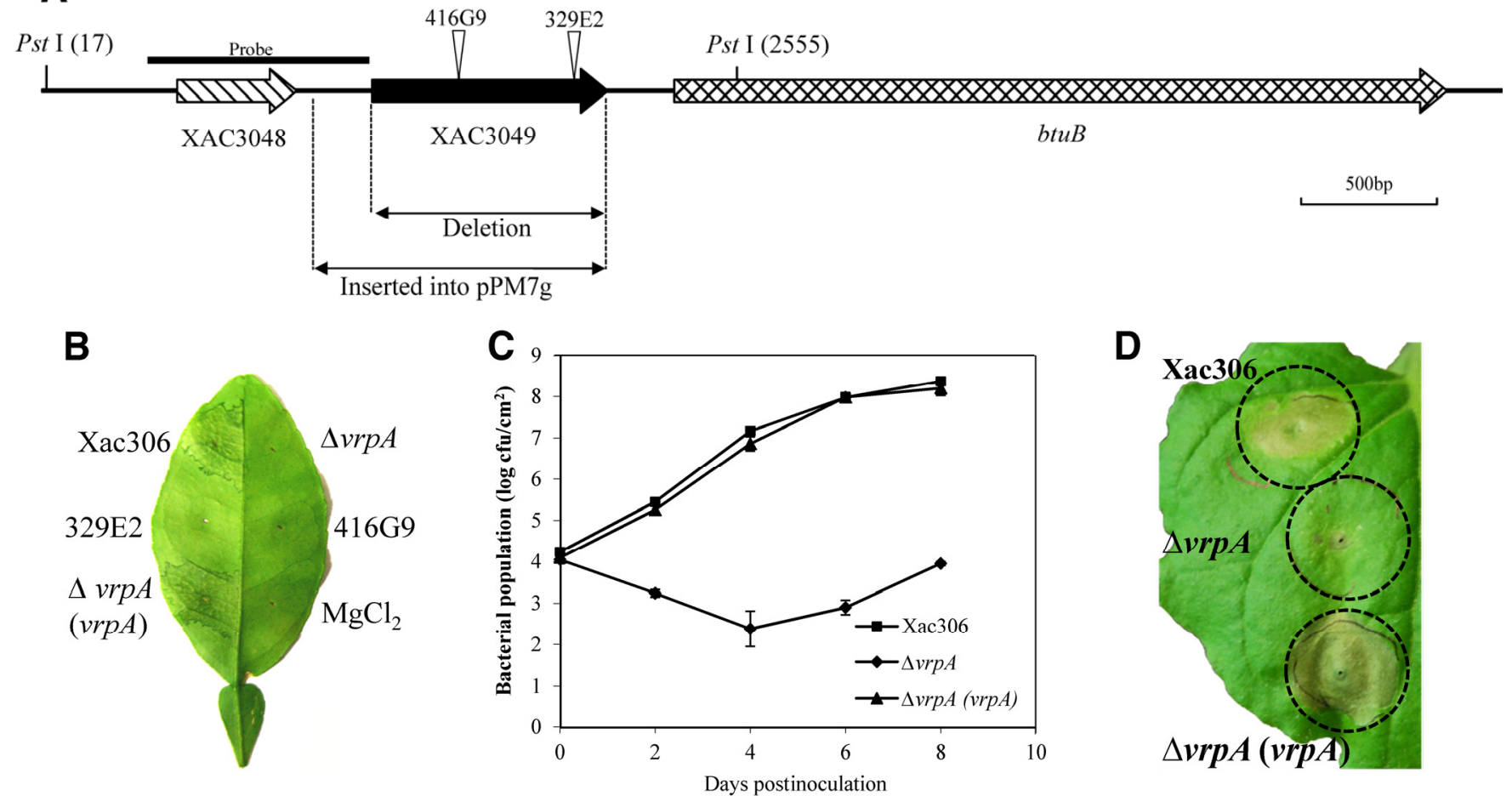

Fig. 1. VrpA is required for virulence in Xanthomonas citri subsp. citri. A, Schematic diagram of vrpA (XAC3049), the upstream XAC3048, and the downstream btuB gene loci. The single-head arrows represent the gene location and orientation. The two Pst I sites used for Southern bolt analyses are located at 17 and 2,555 bp, respectively, from the left end. The EZ-Tn5 insertion sites in both the 416G9 and $329 \mathrm{E} 2$ mutants are indicated. The deletion and complementary regions are shown using dotted lines. B, Pathogenicity assay. Cells were used to inoculate grapefruit leaves (Citrus paradise Macf. 'Duncan') at $10^{6}$ $\mathrm{CFU} \mathrm{ml} \mathrm{m}^{-1}$. Leaves were photographed 6 days postinoculatioin. Experiments were repeated more than three times with similar results, and only one representative leaf is presented. C, X. citri subsp. citri growth curve in planta. The bacterial cells were used to inoculate grapefruit leaves at $10^{6} \mathrm{CFU}^{-1}$, and the leaves were recovered at different time-points. Values represent the means from three replicates. Means \pm standard deviation are plotted. D, Wild type, vrpA mutant, and insertion complementary strain were inoculated into 4-week-old fully expanded leaves of Nicotiana benthamiana at the concentration of $10^{8}$ $\mathrm{CFU} \mathrm{ml} \mathrm{m}^{-1}$. Hypersensitive response induction were observed and photographed around 10 days past-inoculation. All experiments were repeated three times with the similar results, and only one leaf was presented. 
double crossover homologous recombination using the pOK1 suicide plasmid. Southern blot analyses indicated that the entire ORF of the vrpA gene was deleted from the chromosome (Supplementary Fig. S1). The vrpA mutant was subsequently used to inoculate .Duncan. grapefruit and .Valencia. sweet orange. Similar to the insertion mutants 416G9 and 329E2, the $v r p A$ deletion mutant did not cause visible canker symptoms, which indicates a crucial role for $v r p A$ in $X$. citri subsp. citri virulence (Fig. 1B). A similar phenotype was observed using a Valencia sweet orange plant (data not shown). The complementary strain induced canker symptoms typical for wild-type Xac306 on the grapefruit (Fig. 1B) and sweet orange plants (data not shown). In addition, the bacterial growth curve in planta indicated that the wild-type and complementary strain populations were similar, whereas the $v r p A$ mutant population was significantly lower than the wild-type and complementary strains (Fig. 1C). No dramatic difference was observed between growth of the wild-type, complementary, and $v r p A$ mutant strains in nutrient broth (NB), XVM2, M9, and plant-extraction media (Supplementary Fig. S2).

In addition, a tobacco inoculation assay was performed to test whether $\operatorname{VrpA}$ is involved in induction of the hypersensitive response (HR) in nonhost plants. The wild-type, vrpA mutant, and vrpA insertion complementary strains were inoculated on 4-week-old tobacco leaves at a cell density of $10^{8} \mathrm{CFU}$ $\mathrm{ml}^{-1}$ (optical density at $600 \mathrm{~nm}\left[\mathrm{OD}_{600}\right]=0.3$ ) by needless infiltration. The results showed that wild-type 306 and the vrpA insertion complementary strain induced an HR on tobacco leaves at 10 days postinoculation (dpi), while the $\operatorname{vrp} A$ mutant failed to elicit HR or elicited a delayed and weakened HR compared with wild-type and complementary strains (Fig. 1D). Taken together, our results indicate that VrpA is an essential protein contributing to virulence and HR induction.

\section{VrpA is a highly conserved protein}

\section{in phytopathogenic xanthomonads.}

Protein BLAST showed that VrpA in X. citri subsp. citri shares approximately $90 \%$ similarity with its homologs in other Xanthomonas spp. (Supplementary Fig. S3). In addition, Stenotrophomonas and Xylella spp. harbor VrpA homologs of approximately 76 and $65 \%$ identity, respectively. Notably, Pseudoxanthomonas suwonensis 11-1 and Pseudomonas geniculata N1 contain VrpA homologs with the similarities of 76 and $62 \%$, respectively. An N-terminal 23-amino-acid signal peptide was predicted by the SignalP 4.1 program. Interestingly, the SignalP prediction revealed that all of the VrpA's homologs contain an $\mathrm{N}$-terminal signal peptide, which suggests that the evolutionarily conserved VrpA proteins in Xanthomonas spp. and other species may have similar localization and biochemical functions. However, a bioinformatics analysis of the $\operatorname{VrpA}$ protein failed to provide additional insight into its biochemical function, and no known domain and motif was identified.

To test whether the VrpA homologs have similar function, we tested the function of $\mathrm{VrpA}$ in $X$. campestris pv. campestris. The VrpA homolog (XCC2866, designed as $\operatorname{VrpA}_{\mathrm{Xcc}}$ herein) in X. campestris pv. campestris ATCC 33913, which causes black rot on the most cultivated cruciferous vegetables worldwide, including the model plant Arabidopsis thaliana (Vicente and Holub 2013), was knocked out and the virulence of $v r p A_{X c c}$ mutant was tested. Wild-type Xcc33913 induced chlorotic and necrotic symptoms on Arabidopsis ecotype Col0 at $5 \mathrm{dpi}$, while the $v r p A_{X c c}$ mutant-inoculated leaves remained symptomless (Fig. 2A). Introducing the complementation plasmid p53-VrpA $A_{X c c}$ restored virulence in the $\operatorname{vrp} A_{X c c}$ mutant. In addition, the VrpA homologs in $X$. campestris pv. campestris and $X$. campestris pv. vesicatoria, which causes bacterial leaf spot on pepper and tomato, complemented the virulence of an
$X$. citri subsp. citri vrpA mutant. At 7 dpi, the $X$. citri subsp. citri vrpA mutants with $\mathrm{p} 53-\mathrm{Vrp} \mathrm{A}_{\mathrm{Xcc}}$ and $\mathrm{p} 53-\mathrm{Vrp} \mathrm{A}_{\mathrm{Xcv}}$ induced typical citrus canker symptoms, similar to wild-type 306 (Fig. 2B). The in planta bacterial population indicated that ectopic
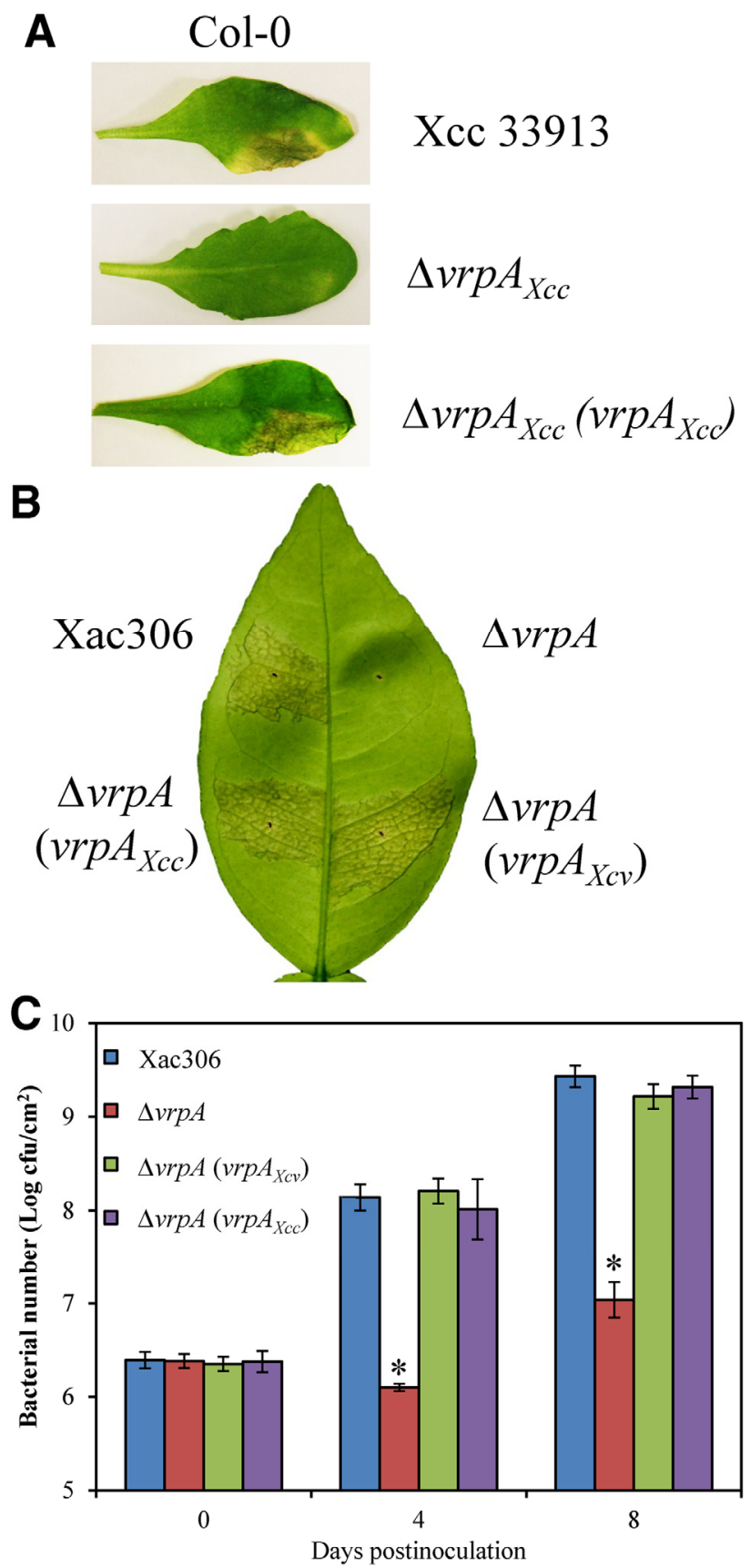

Fig. 2. $\operatorname{Vrp} A_{X a c}$ and its homologs $\operatorname{Vrp} A_{X c c}$ and $\operatorname{Vrp} A_{X c v}$ are functionally conserved. A, Pathogenicity assay for Xanthomonas campestris pv. campestris on the Arabidopsis thaliana ecotype Col-0. Leaves were infiltrated with the wild type, a $v r p A_{X c c}$ mutant, and a complementary strain of $X$. campestris pv. campestris 33913 using a bacterial suspension adjusted to $5 \times 10^{5} \mathrm{CFU} \mathrm{ml}{ }^{-1}$. Photographs were collected 5 days postinoculatioin (dpi). B, Pathogenicity assay for X. citri subsp. citri in citrus. Bacterial cells were used to inoculate Duncan grapefruit leaves at $10^{8} \mathrm{CFU} \mathrm{ml}{ }^{-1}$. Leaves were photographed 6 dpi. Pathogenicity assays using Arabidopsis and citrus were repeated more than three times with similar results, and only one representative leaf is presented. C, X. citri subsp. citri bacterial population in Duncan grapefruit. Bacterial cells were used to inoculate Duncan grapefruit leaves at $10^{8} \mathrm{CFU} \mathrm{ml}^{-1}$. Bacterial cells were recovered from the inoculated leaves 0,4 , and $8 \mathrm{dpi}$, and the values are the means from three repeats. Means \pm standard deviation are plotted. Asterisks indicate a statistically significant difference (* indicates $P<0.01$ versus the wild type). 
expression of $\operatorname{VrpA}_{\mathrm{Xcv}}$ and $\operatorname{Vrp} \mathrm{A}_{\mathrm{Xcc}}$ restored the growth of the $X$. citri subsp. citri vrpA mutant to wild-type level (Fig. 2C). Although $\operatorname{VrpA}_{\mathrm{Xcv}}$ and $\operatorname{Vrp}_{\mathrm{Xcc}}$ contain 2 amino acid mutations (A18P and G130T) and 13 amino acid mutations (Y3H, M12 L, T19S, Q27A, L20I, S77T, G122A, G129N, G131A, V133A, A146S, S270N, and V279I), respectively, compared with $\operatorname{VrpA}$ in $X$. citri subsp. citri, our results suggest that VrpA and its tested homologs are functionally conserved.

\section{VrpA is localized and functional in the periplasm.}

VrpA contains a 23-amino-acid signal peptide at the $\mathrm{N}$ terminus and the cleavage site was predicted to be between amino acids 23 to 26 . To examine whether VrpA is secreted to bacterial periplasm, we made an $\mathrm{N}$-terminal 26-amino-acid deletion mutant, $\operatorname{VrpA}_{\Delta \mathrm{N} 26}$, which lacks a complete signal peptide. The full-length VrpA protein and truncated mutant were expressed in pTF53 plasmid in-frame with a 3xFLAG tag, and the corresponding constructs were ectopically expressed in the $v r p A$ mutant under the control of the $\mathrm{P}_{\text {trp }}$ promoter. Cells expressing $\operatorname{VrpA}-\mathrm{FLAG}$ and $\mathrm{VrpA}_{\Delta \mathrm{N} 26}$-FLAG were harvested at the stationary phase and fractionated into a cytoplasm and membrane $(\mathrm{CM})$ fraction and a periplasmic (PP) fraction through osmotic shock, whereas the bacterial culture supernatant (SN) yielded the extracellular fraction (EC) (Matsui et al. 2009). The fractions and total extracts (TEs) were subjected to immunoblotting using an anti-FLAG antibody to detect VrpA. RNA polymerase was exclusively observed in the TE and the
CM fraction but not in the PP fraction (Fig. 3A), suggesting no bacterial lysis occurred and there was similar protein loading. As expected, VrpA-FLAG was only present in the PP fraction but not the CM fraction. $\operatorname{VrpA}_{\Delta \mathrm{N} 26}$-FLAG was only detected in the CM fraction but not the PP fraction. Neither VrpA-FLAG nor $\operatorname{VrpA}_{\Delta \mathrm{N} 26}$-FLAG were detected in the EC fraction, which suggests that VrpA is not secreted into the extracellular environment (data not shown).

To further confirm that VrpA is localized in the periplasm, an E. coli-based alkaline phosphatase (PhoA) assay was performed (Ammerman et al. 2008). PhoA is active only when translocated after export to the periplasm, and the phosphatase activity can be visually detected by adding a chromogenic substrate 5-bromo-4-chloro-3-indolyl phosphate (BCIP) to the bacterial medium (Bronstein et al. 2005). To generate pJDTVrpA and pJDT-VrpA ${ }_{\Delta \mathrm{N} 26}$, the full-length $\operatorname{VrpA}$ and truncation mutant were fused in-frame with the PhoA $\mathrm{N}$ terminus devoid of its native signal peptide. Two plasmids and an empty vector control were transformed into E. coli DH5 $\alpha$ cells. The transformants were streaked on Luria-Bertani (LB) plates containing BCIP at $90 \mu \mathrm{g} \mathrm{ml}^{-1}$ and ampicillin (Amp) at $100 \mu \mathrm{g} \mathrm{ml}^{-1}$. The cell colonies with pJDT-VrpA turned blue, whereas the cell colonies with pJDT-VrpA ${ }_{\Delta \mathrm{N} 26}$ and an empty vector did not (Fig. 3B). In summary, our localization studies suggest that VrpA is secreted into the bacterial periplasm.

The periplasmic localization prompted us to postulate that VrpA is functional in the periplasm, and the signal peptide is

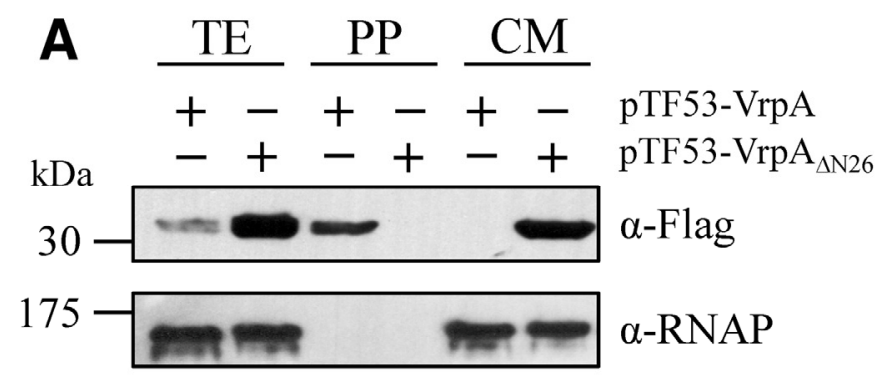

B
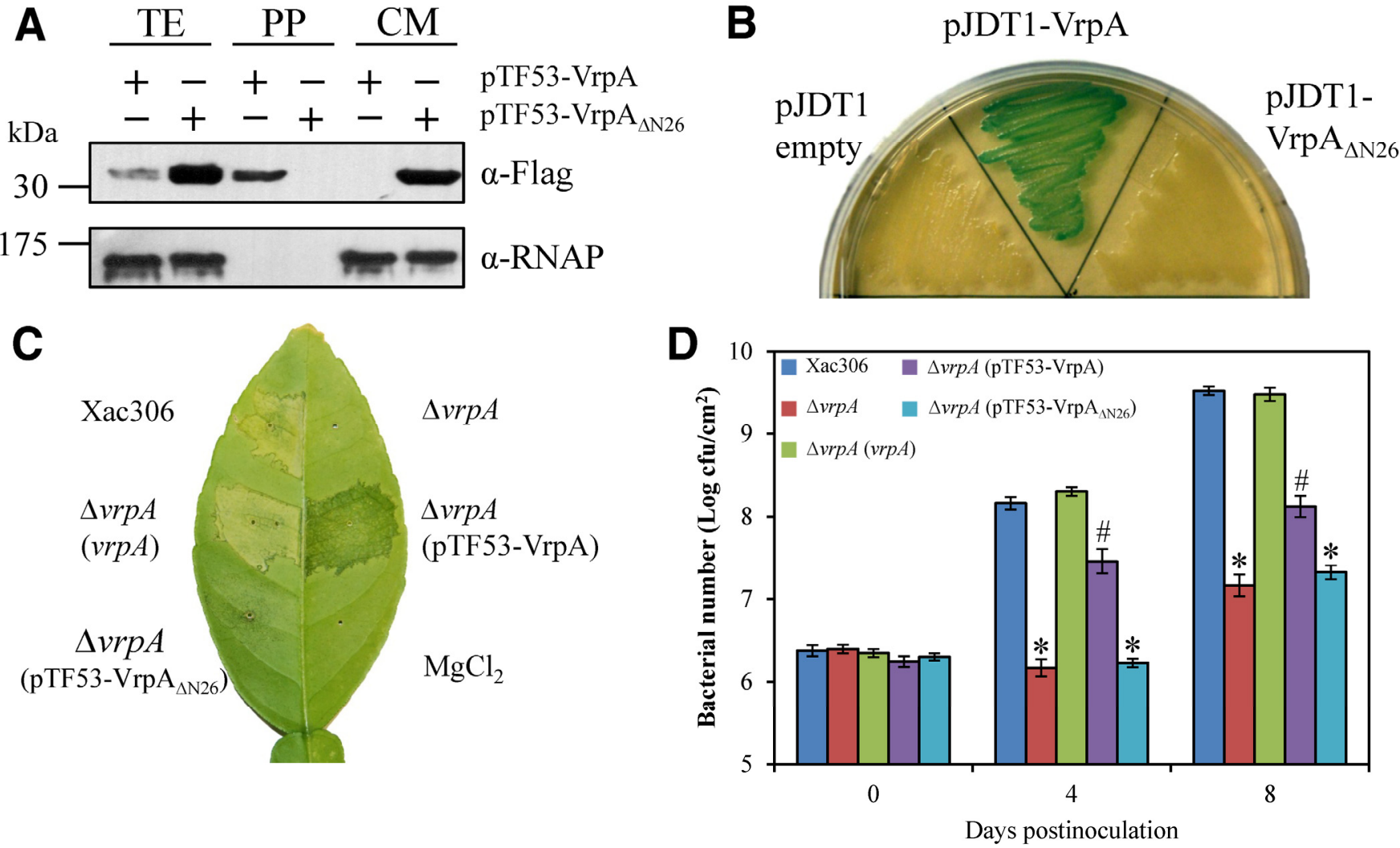

Fig. 3. VrpA is localized and functional in the bacterial periplasm. A, VrpA detection in different cell fractions through immunoblotting. The $v r p A$ mutant expressing full-length VrpA-Flag or $\mathrm{VrpA}_{\Delta \mathrm{N} 26}$-Flag was inoculated in XVM2 medium, and fractions enriched in the cytoplasm and membrane (CM) and periplasm (PP) were separated by osmotic shock. Total extract (TE), CM. and PP fractions were analyzed through immunoblotting using antibodies specific for the FLAG tag and RNA polymerase (control). B, Alkaline phosphatase gene fusion assay. Escherichia coli strains carrying pJDT1-VrpA, pJDT1$\operatorname{VrpA}_{\Delta \mathrm{N} 26}$, and an empty vector were streaked onto Luria-Bertani plates supplemented with 5 -bromo-4-chloro-3-indolyl phosphate at $90 \mu \mathrm{g} \mathrm{m}^{-1}$, $75 \mathrm{mM}^{-}$ $\mathrm{Na}_{2} \mathrm{HPO}_{4}$, and ampicillin at $100 \mu \mathrm{g} \mathrm{ml}{ }^{-1}$. C, Pathogenicity assay for citrus. Bacterial cells from different $X$. citri subsp. citri strains were used to inoculate grapefruit leaves at $10^{6} \mathrm{CFU} \mathrm{ml}^{-1}$. Photographs were collected 6 days postinoculatioin (dpi). D, $X$. citri subsp. citri strain bacterial populations in planta were determined 0,4 , and $8 \mathrm{dpi}$ with the initial bacterial concentration $10^{8} \mathrm{CFU} \mathrm{ml}{ }^{-1}$. All experiments were repeated more than three times with similar results, and only one representative leaf is presented. Means \pm standard deviation are plotted. Asterisks and pounds denote a statistically significant difference (* indicate $P<0.01$ versus wild type and \# indicates $P<0.01$ versus wild type and $v r p A$ mutant). 
required for virulence. To test this hypothesis, the wild type, a vrpA mutant, a chromosomal insertion complementary strain, and a $\operatorname{vrp} A$ mutant with constitutive VrpA-FLAG or $\operatorname{VrpA}_{\Delta \mathrm{N} 26^{-}}$ FLAG expression were used to inoculate Duncan grapefruit leaves at $10^{8} \mathrm{CFU} \mathrm{ml} \mathrm{m}^{-1}\left(\mathrm{OD}_{600}=0.3\right)$. The wild-type, chromosomal insertion complementary, and full-length VrpA-FLAGexpressing strains produced citrus canker symptoms (Fig. 3C). However, the $\operatorname{vrpA}$ mutant and $\operatorname{VrpA}_{\Delta \mathrm{N} 26}$-FLAG-expressing strains did not induce citrus canker symptoms (Fig. 3C). In addition, bacterial populations of the wild-type, insertion complementary, and VrpA-FLAG-expressing strains were significantly higher than the $v r p A$ mutant and $\operatorname{VrpA}_{\Delta \mathrm{N} 26}$-FLAGexpressing strains (Fig. 3D). The reduced population of VrpAFLAG expressing cells was observed and may be due to the accumulation of secretory proteins being toxic to the cell (Schlegel et al. 2013). Taken together, our results strongly support the notion that VrpA is a periplasmic protein secreted via a Sec-dependent pathway, and VrpA's periplasmic localization is required for its function in $X$. citri subsp. citri virulence.

\section{VrpA contributes to secretion}

of T3SS proteins and effectors via T3SS.

Due to the significant effect of vrpA mutation on $X$. citri subsp. citri virulence and HR induction, we postulated that VrpA affects T3SS, which is crucial for pathogenicity and HR induction of many gram-negative phytopathogenic bacteria (e.g., Xanthomonas, Pseudomonas, Erwinia, and Ralstonia spp.) (Büttner 2012; Büttner and He 2009). To determine whether VrpA plays a role in protein secretion via T3SS, an adenylate cyclase (CyaA) fusion assay was performed (Sory et al. 1995). The CyaA is a calmodulin-dependent reporter protein that produces measurable cyclic AMP (cAMP) levels only when it is inside a plant cell but not in bacteria or the plant apoplast. The first 100 amino acids of an exogenous effector protein, AvrXv4, were used to fuse with CyaA. The AvrXv4 $4_{1-100}::$ CyaA construct was introduced into the wild type, vrpA mutant, insertion complementary strain, and T3SS component $h r c V$ and $h r c N$ mutants. Similar expression levels and stability of the chimeric protein in all transformants were observed by immunoblot in XVM2 medium (Supplementary Fig. S4A). The corresponding strains were used to inoculate tobacco leaves at $10^{8} \mathrm{CFU} \mathrm{ml}{ }^{-1}\left(\mathrm{OD}_{600}=\right.$ 0.3 ), and the cAMP levels were measured $24 \mathrm{~h}$ postinoculation. cAMP levels in the leaves inoculated with wild-type or insertion complementation strains were significantly higher than those inoculated the with vrpA mutant and T3SS-defective $h r c V$ and

Fig. 4. VrpA affects protein translocation through a type III secretion system (T3SS). A, Adenylate cyclase (CyaA) translocation assay. The AvrXv4 ${ }_{1-100}$-CyaA fusion construct was transferred into the wild type, a $v r p A$ mutant, the inserted complementary strain, and the $h r c V$ and $h r c N$ mutants. The derivative strains were then used to inoculate Nicotiana benthamiana leaves. The cAMP level was determined $24 \mathrm{~h}$ postinoculation. Standard errors are indicated. Each experiment was repeated at least twice with similar results. B, Relative fold-change expression levels of CsLOBI were determined using a quantitative reverse-transcription polymerase chain reaction after inoculation with wild-type 306, vrpA mutant, inserted complementary strain, pthA4 mutant, and two T3SS-deficient mutants, $\Delta h r c V$ and $\Delta h r c N$. Bacterial strains were used to inoculate sweet orange at $10^{8} \mathrm{CFU} \mathrm{ml}{ }^{-1}$. The total RNA from inoculated zone was isolated and analyzed 0,10 , and $20 \mathrm{~h}$ postinoculation. Fold change values are shown as $2^{-\triangle \triangle C \mathrm{~T}}$ and were normalized to $C s L O B 1$ expression at $0 \mathrm{~h}$ after wild-type infiltration and to glyceraldehyde-3-phosphate dehydrogenase (GAPDH) (Cs5g06870) as an internal control for equal total RNA input. Error bars are indicated. C, Protein in vitro secretion assay. Strains $85^{*}$ (wild type) and $85^{*} \Delta v r p A$ harboring pGM-AvrGf1, pTF53-XopN, pTF53-HrpF, and pTF53-HrpE were incubated in a secretion-inducing medium. The total protein extraction (TE) and supernatant $(\mathrm{SN})$ fractions were analyzed through immunoblotting.
hrcN mutants (Fig. 4A). These experiments showed that VrpA affects T3E secretion via T3SS.

A recent study showed that $C s L O B 1$ is a citrus canker susceptibility gene that induces pustule formation, and the expression of CSLOB1 can be induced by a transcription activatorlike effector (TALE) PthA4 in X. citri subsp. citri (Hu et al. 2014). Thus, CsLOB1 expression level can be used to evaluate PthA4 translocation in the $v r p A$ mutant strain compared with the wild type. For this test, the wild type, $v r p A$ mutant, inserted complementary strain, pthA4 mutant, and $h r c V$ and $h r c N$ mutants were used to inoculate Valencia sweet orange at $10^{8}$

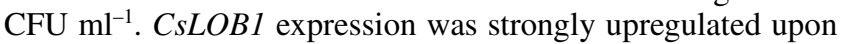
inoculation of the wild-type and complementary strains. However, the $v r p A$ mutant as well as $h r c V$ and $h r c N$ mutants failed to induce the expression of $C S L O B 1$ to the wild-type level (Fig. 4B), indicating that translocation of PthA4 by the T3SS was compromised in $\operatorname{vrpA}$ mutant.
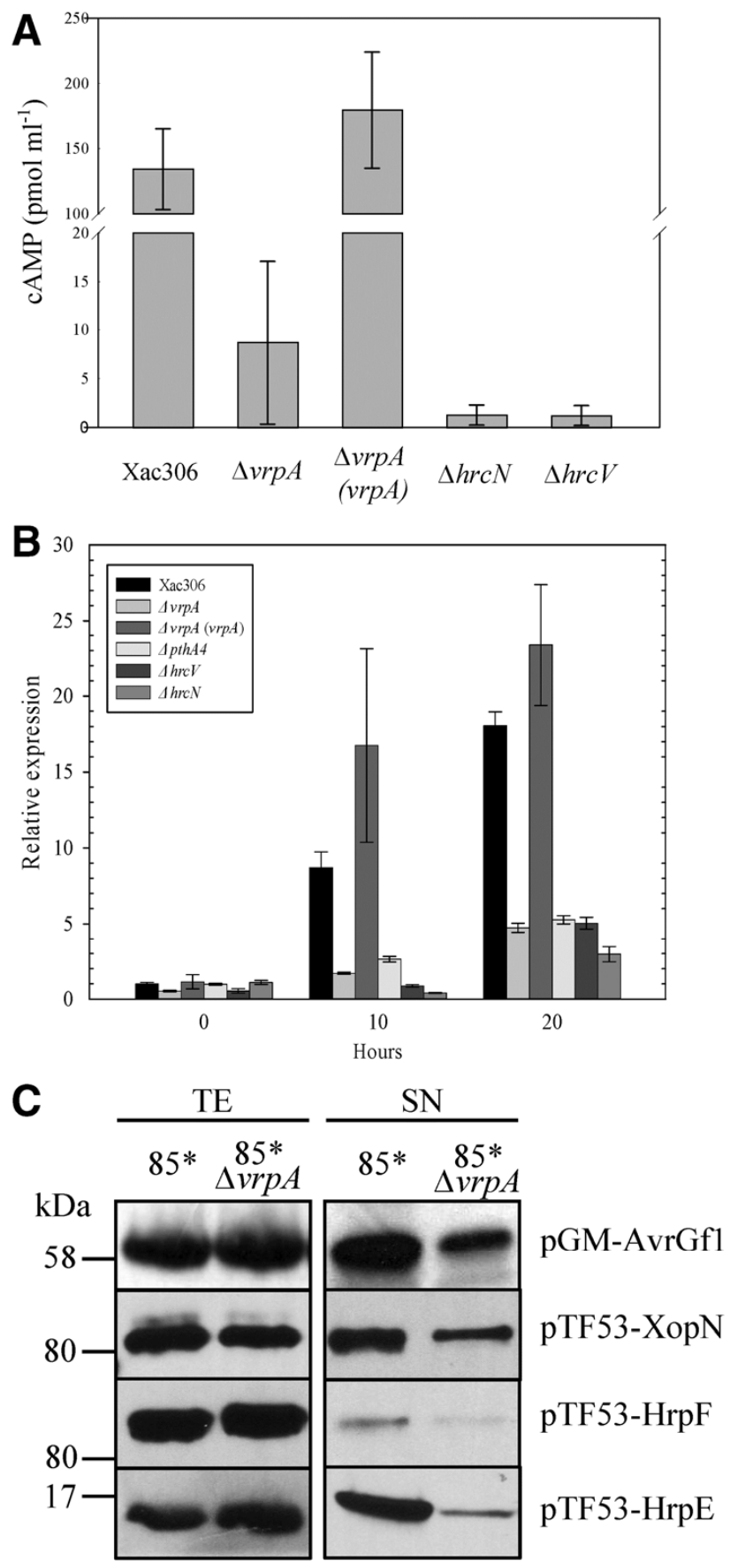
The effect of VrpA on secretion of T3SS proteins and T3Es was further tested using an extracellular secretion assay with $X$. campestris pv. vesicatoria $85^{*}$ and the $85^{*}$ vrpA mutant instead of $X$. citri subsp. citri strains because $X$. campestris pv. vesicatoria $85^{*}$ expresses a constitutively activated form of $h r p G\left(h r p G^{*}\right)$; therefore, T3SS is constitutively activated in $X$. campestris pv. vesicatoria 85* (Rossier et al. 1999; Wengelnik et al. 1999). The constitutively activated T3SS in X. campestris pv. vesicatoria $85^{*}$ renders it easy to measure the T3SS secretion in vitro. We investigated secretion of the $X$. citri subsp. citri specific effector AvrGF1, the XopN proteins that are present in both $X$. citri subsp. citri and X. campestris pv. vesicatoria, T3SS pilus protein HrpE, and translocon proteins HrpF. Protein samples from the TE and culture SN were isolated and used for immunoblotting. RNA polymerase was used as a control to ensure that no detectable bacteria lysis occurred. Secretion of all analyzed proteins was reduced in the vrpA mutant compared with the wild type (Fig. 4C), suggesting that VrpA plays a significant role in secretion of T3SS proteins and T3Es. Intriguingly, we also observed that $\Delta v r p A_{X c c}$ was unable to induce HR on nonhost tobacco; the concentration of cAMP in the $\Delta v r p A_{X c c}$-inoculated leaves was approximately fourfold lower than the wild type (Supplementary Fig. S5). In summary, our data indicate that VrpA contributes to secretion of T3SS proteins and effectors via T3SS.

\section{VrpA interacts with periplasmic domains of HrcJ and HrcC.}

Because VrpA is localized to the bacterial periplasm and contributes to protein secretion through $\mathrm{T} 3 \mathrm{SS}$, we postulated that
VrpA may directly or indirectly associate with the T3SS apparatus (i.e., periplasmic components). To investigate whether VrpA physically interacts with the T3SS periplasmic components, we performed a yeast-two hybrid (Y2H) assay to analyze the interactions between VrpA and five T3SS apparatus proteins: HrcJ, HrcC, HrpB1, HrpB2, and HrpD5. In animal pathogens, crystal structure studies revealed that EscD/PrgH/YscD family and $\mathrm{EscJ} / \mathrm{PrgK} / \mathrm{YscJ}$ family proteins are major components of the IM ring and EscC/InvG family members form the OM ring (Marlovits et al. 2004). Periplasmic domains of the OM and IM rings interact and compose the T3SS periplasmic rod (Spreter et al. 2009). HrpD5, HrcJ, and HrcC are isoforms of the EscD, EscJ, and EscC families, respectively. Recent studies show that HrpB2 is a periplasmic protein that interacts with HrpB1 in $X$. campestris pv. vesicatoria (Hartmann et al. 2012; Hausner et al. 2013). Because HrpD5, HrcJ, and HrcC are partially localized in the periplasm and contain a transmembrane domain, which may yield false-negative results, we used the periplasmic region of each protein without the transmembrane domain fused to the GAL4 DNA binding domain (BD) to monitor the interaction of the native form of $\operatorname{VrpA}_{\Delta \mathrm{N} 26}$ fused to the GAL4 activation domain (AD), as indicated (Fig. 5A). The SV40-p53 interaction was used as the positive control. The cells grown on double dropout medium (DDO) without tryptophan and leucine indicate that both the $\mathrm{BD}$ and $\mathrm{AD}$ vectors were successfully co-transformed into the Y2HGold strain (Fig. 5A, left panel). Two reporter genes, AUR-C and MEL1, were used to detect the positive protein interactions that enable yeast cells to grow on DDO plates in the presence of the highly toxic drug Aureobasidin A and to show a blue color upon adding the chromogenic substrate

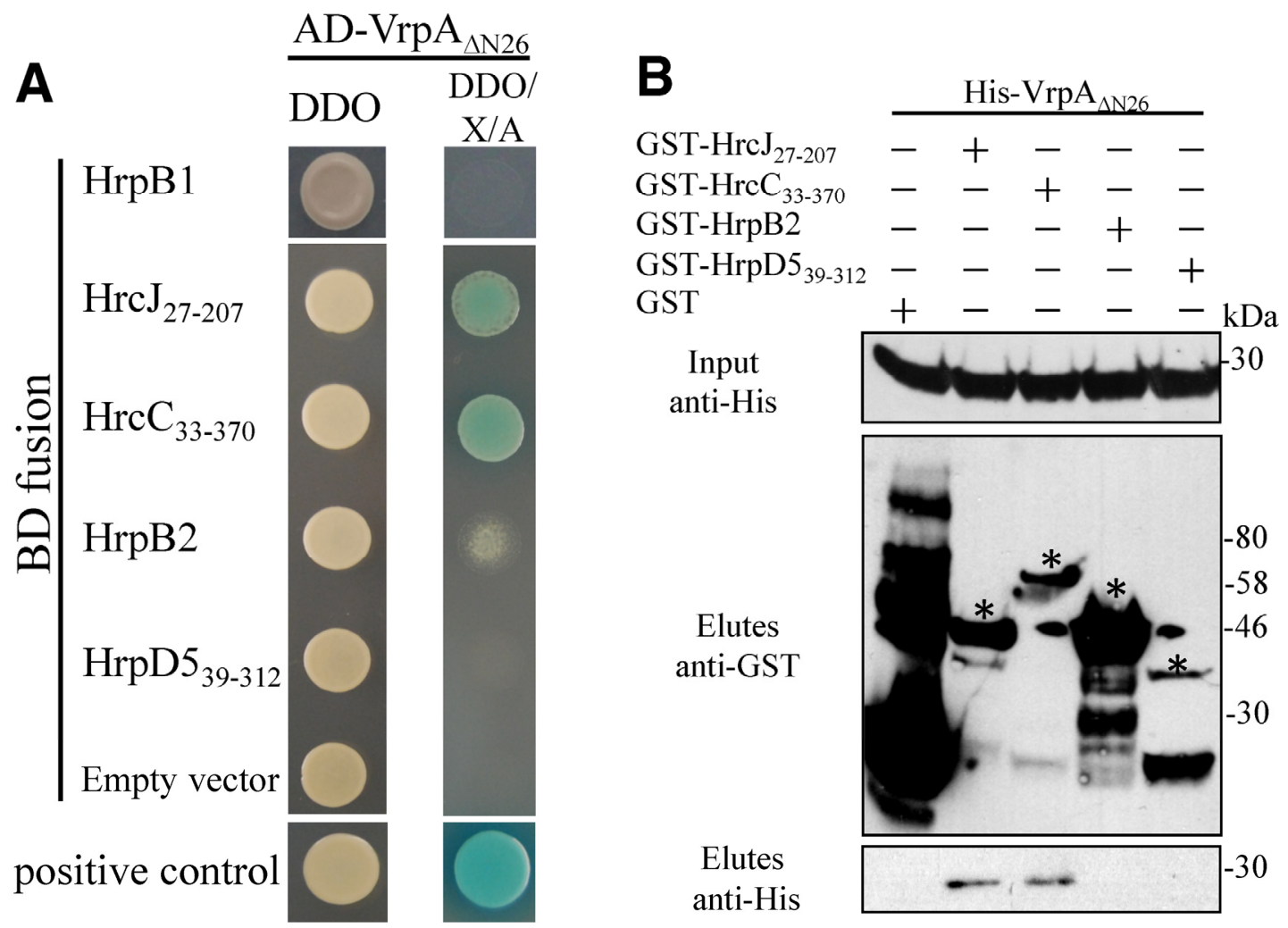

Fig. 5. VrpA interacts with the periplasmic domains of $\mathrm{HrcJ}$ and HrcC. A, Yeast-two hybrid (Y2H) assay. Full-length HrpB1, HrcJ $27-207$, HrcC $33-370$, fulllength HrpB2, and $\mathrm{HrpD}_{539-312}$ fused to the GAL4 DNA binding domain (BD) were expressed in combination with VrpA $\mathrm{AN}_{26}$ fused to the GAL4 activation domain (AD) in the yeast strain Y2HGold. Strains were grown on double dropout medium (DDO) with -Trp and -Leu (left panel) as well as on DDO medium supplemented with X- $\alpha-$ Gal and Aureobasidin A (DDO/X/A, right panel). SV40 large T-antigen (fused with BD) and murine p53 (fused with AD) were used as positive controls; the empty BD vector was used as the negative control. B, Glutathione-S-transferase (GST) pull-down assay. GST-HrcJ $27-207$, GST$\mathrm{HrcC}_{33-370}$, GST-HrpB2, and GST-HrpD ${ }_{539-312}$ were expressed in Escherichia coli, immobilized on glutathione sepharose beads, and incubated with E. coli lysates containing His-VrpA $\mathrm{N}_{\mathrm{N} 26}$. Total cell extract (Input) and eluted protein (Elute) were immunoblotted using the anti-GST and anti-His antibody. Asterisks indicate GST fusion proteins. 
$\mathrm{X}-\alpha-\mathrm{Gal}$. All proteins synthesized in yeast strains were subjected to immunoblotting analysis (Supplementary Fig. S6). The results showed that $\mathrm{HrcJ}_{27-207}$ and $\mathrm{HrcC}_{33-370}$ but not $\mathrm{HrpB} 1$, HrpB2, and $\operatorname{HrpD}_{539-312}$ interact with $\operatorname{VrpA}_{\Delta \mathrm{N} 26}$ (Fig. 5A). To confirm these interactions, a glutathione- $S$-transferase (GST) pull-down assay was performed (Fig. 5B). The E. coli cell lysates that expressed GST-HrcJ $\mathrm{J}_{27-207}$, GST-HrcC $33-370$, GSTHrpB2, GST-HrpD $539-312$, and GST (negative control) were bound to glutathione sepharose beads and mixed with His$\mathrm{VrpA}_{\Delta \mathrm{N} 26^{-}}$expressing cell lysate. After incubation for $2 \mathrm{~h}$, the GST fusion proteins were washed and eluted. The eluted proteins were immunoblotted to detect GST-fused proteins and His$\operatorname{VrpA}_{\Delta \mathrm{N} 26}$. Specific signals were detected only in the $\mathrm{HrcJ}_{27-207}$ and $\mathrm{HrcC}_{33-370}$ elutions, which indicates that VrpA can interact with $\mathrm{HrcJ}$ and $\mathrm{HrcC}$ in vitro (Fig. 5B). Taken together, our results suggest that VrpA physically interacts with the periplasm domain of $\mathrm{HrcJ}$ and $\mathrm{HrcC}$ proteins.

\section{The expression of VrpA is induced in planta and in XVM2 but the mutation of VrpA does not affect $h r p$ or $h r c$ gene expression.}

In light of the intimate connection between VrpA and T3SS, we investigated the gene expression of VrpA and T3SS proteins. We found that $v r p A$ is induced in citrus plants and plant-mimic medium XVM2 (Supplementary Fig. S7). Total RNA was isolated from inoculated leaves at 4, 7, or 14 dpi. The quantitative reverse-transcription polymerase chain reaction (QRT-PCR) revealed that the expression of $v r p A$ was induced in planta at 4 dpi, culminated at $7 \mathrm{dpi}$, and reduced again after $14 \mathrm{dpi}$. In XVM2, the total RNA was extracted from inoculated bacteria at early stationary phase. The $v r p A$ gene expression level in XVM2 was approximately fivefold higher than that in NB medium. In addition, we investigated the expression of T3SS genes $h r c Q$, $h r c U$, and $h r p B 1$ and two T3SS master regulators, $h r p G$ and $h r p X$, in the wild type and $v r p A$ mutant. QRT-PCR results showed that all tested genes had a similar expression level in the wild type and mutant. HrpG can be activated by a sensor kinase HpaS through phosphorylation and upregulates the expression of HrpX, which binds to a consensus sequence motif (TTCGCN15-TTCGC) located in a plant-inducible promoter (PIP), known as PIP box, to promote T3SS gene expression (Fenselau and Bonas 1995; Guo et al. 2011; Li et al. 2013). However, no PIP box was identified at the upstream sequence of $v r p A$, suggesting that the expression of $v r p A$ is $h r p X$ independent. In support of this, previous studies have shown that $v r p A$ is not regulated by HrpX or HrpG (Guo et al. 2011; Kogenaru et al. 2012).

\section{VrpA is involved in $X$. citri subsp. citri tolerance against oxidative stress.}

Because VrpA is a periplasmic protein, we hypothesized that VrpA may be involved in tolerance against environmental stresses. The $v r p A$ mutant showed reduced tolerance against $\mathrm{H}_{2} \mathrm{O}_{2}$ compared with the wild-type strain because the vrpA mutant exhibited the lower (Student's $t$ test, $P<0.05$ ) $\mathrm{OD}_{600}$ at $100,150,200$, and $250 \mu \mathrm{M} \mathrm{H}_{2} \mathrm{O}_{2}$ compared with the wild type (Supplementary Fig. S8). We also examined other virulence traits (e.g., biofilm formation, lipopolysaccharide [LPS], and exopolysaccharide [EPS]) of the $\operatorname{vrpA}$ mutant and the wildtype strains. No difference was observed for biofilm formation, LPS, and EPS between the vrpA mutant and the wild-type strains (Supplementary Fig. S9).

\section{DISCUSSION}

Our study indicates that VrpA is required for efficient protein secretion via T3SS, which is supported by multiple lines of evidence. The CyaA gene fusion assay (Fig. 4A) showed that the T3E secretion in $v r p A$ mutant was reduced. This reduced secretion was also supported by reduced expression of citrus $C s L O B 1$ gene (Fig. 4B). CsLOB1 was identified as the susceptibility gene for citrus canker. PthA4, a TALE in $X$. citri subsp. citri, induces hypertrophy and hyperplasia by binding to the effector binding element in the promoter of the CsLOB1 gene to activate transcription of the CsLOBI (Hu et al. 2014). No hypertrophy and hyperplasia symptoms were observed on Duncan grapefruit with inoculation of $v r p A, p t h A 4, h r c V$, and $h r c N$ mutants, which further supported the notion that $C s L O B 1$ induction was compromised or abolished in the mutants compared with the wild type under the experimental conditions. Moreover, the in vitro secretion studies showed a reduced secretion of T3SS pilus, translocon, and two effector proteins, indicating that full function of T3SS was systematically affected (Fig. 4). Therefore, it is conceivable that $X$. citri subsp. citri vrpA mutant has a much reduced virulence compared with the wild-type strain. The similar expression level of $h r p$ or $h r c$ genes in the wild type and vrpA mutant suggests that VrpA regulates T3SS through a novel mechanism rather than regulating T3SS gene expression. We did observe similar expression patterns of $v r p A$ and $h r p$ genes in planta and in XVM2 (Astua-Monge et al. 2005; Jalan et al. 2013). However, $v r p A$ is not regulated by $\mathrm{HrpX}$ or HrpG, the master regulators for $h r p$ genes (Guo et al. 2011; Kogenaru et al. 2012). No PIP box was identified in the promoter region of the $v r p A$ gene. Overall, our data suggest that the hrp genes and $v r p A$ are not coexpressed despite the effect of VrpA on T3SS.

The effect of VrpA on tolerance against oxidative stress likely contributes to the virulence deficiency of the $v r p A$ mutant. Plants produce an oxidative burst, an important component of the plant defense responses, that characterizes an excessive amount of reactive oxygen species (ROS), which are toxic derivatives of oxygen, including superoxide anion $\left(\mathrm{O}^{2-}\right)$, hydrogen peroxide $\left(\mathrm{H}_{2} \mathrm{O}_{2}\right)$, and hydroxyl radical $(\mathrm{OH} \bullet)$ (Baker and Orlandi 1995; Hammond-Kosack and Jones 1996). The oxidative burst by plants in response to microbial pathogen attack has been reported in both compatible and incompatible interactions (Bolwell et al. 2002; Wojtaszek 1997). Peak concentrations of $\mathrm{H}_{2} \mathrm{O}_{2}$ were observed at $24 \mathrm{~h}$ and between 8 and 10 days after inoculation in sweet orange .Hamlin. infected by $X$. citri subsp. citri (Kumar et al. 2011). ROS are capable of oxidizing DNA, lipid membranes, and proteins to result in cell damage (Lee et al. 2004; Levine et al. 1994). Thus, the ROS encountered by the $v r p A$ mutant in planta may contribute to its reduced growth (Fig. 1). How VrpA contributes to tolerance against oxidative stress remains to be determined.

Our data indicate that VrpA in $X$. citri subsp. citri localizes to the bacterial periplasmic space, and periplasmic localization is required for full VrpA function and X. citri subsp. citri virulence (Fig. 3). In gram-negative bacteria, the periplasmic space is responsible for establishing a connection between the extracellular environment and bacterial intracellular biochemical reaction; thus, proteins localized to the periplasm often play a role in protein quality control and signal transduction during bacterial pathogenesis (Merdanovic et al. 2011). Due to the periplasmic localization of $\operatorname{VrpA}$, we investigated the protein interaction of VrpA with the T3SS periplasmic component proteins. VrpA interacted with the periplasmic domain of HrcJ and $\mathrm{HrcC}$, which was demonstrated using the $\mathrm{Y} 2 \mathrm{H}$ and GST pull-down assays (Fig. 5). This physical interaction is specific because no interaction was observed for $\operatorname{VrpA}$ with $\operatorname{HrpB} 1$, HrpB2, and HrpD5. HrcJ and HrpD5 are major components of the IM ring, whereas $\mathrm{HrcC}$ is an OM ring component (Marlovits et al. 2004) with periplasmic domains that compose the T3SS periplasmic rod (Spreter et al. 2009). HrpB2 is required for the formation of the inner rod of T3SS (Hartmann et al. 2012; 
Hausner et al. 2013), which might explain why VrpA does not physically interact with HrpB2. Our results suggest that VrpA may affect protein secretion of T3SS by physically interacting with T3SS periplasmic components, which most likely affects activation of secretion and assembly or stability of the T3SS apparatus.

VrpA is conserved in Xanthomonas spp. VrpA and its homologs most likely play a similar role in virulence in Xanthomonas spp. Our results show that mutation of both $v r p A_{X a c}$ and $v r p A_{X c c}$ significantly reduce $X$. citri subsp. citri and $X$. campestris pv. campestris virulence (Figs. 1 and 2). $v r p A_{X c v}$ and $v r p A_{X c c}$ complemented the vrpA X. citri subsp. citri mutant (Fig. 2B and C). However, vrpA homologs were also identified in other genera of the Xanthomonadaceae family; for example, Xylella (Simpson et al. 2000), Rhodanobacter (Weon et al. 2007), Stenotrophomonas (Ramos et al. 2011), and Pseudoxanthomonas (Yoo et al. 2007). but not in other families, except for Xanthomonadaceae. Xylella, Rhodanobacter, Stenotrophomonas, and Pseudoxanthomonas do not contain the T3SS, and the latter three genera are not plant pathogens. Thus, we expect that $v r p A$ may have other functions in addition to its interaction with the T3SS, which is beyond the scope of this study.

In conclusion, we have provided a mechanistic understanding of the hypothetical periplasmic protein VrpA. We confirmed that VrpA is required for virulence of the canker pathogen $X$. citri subsp. citri and black rot pathogen $X$. campestris pv. campestris. VrpA is localized and functional in the bacterial periplasmic space and affects protein secretion via T3SS. VrpA physically interacts with the T3SS periplasmic components $\mathrm{HrcJ}$ and $\mathrm{HrcC}$. Currently, the three-dimensional structure of the T3SS apparatus is unknown because it is not amenable to $\mathrm{X}$-ray crystallography and solution nuclear magnetic resonance due to its inherent noncrystallinity and insolubility (Loquet et al. 2012). Physical interaction between $\operatorname{VrpA}$ and $\mathrm{HrcJ}$ as well as HrcC may aid in understanding the regulation of T3SS secretion. Additionally, VrpA may be an ideal drug target for citrus canker control because it is highly conserved in phytopathogenic xanthomonads and is absent in most environmental microbes and animal pathogens.

\section{MATERIALS AND METHODS}

Bacterial strains, growth conditions, primers, and plasmids.

The bacterial strains and plasmids used in this study are listed in Supplementary Table S1. The primers used in this study are listed in Supplementary Table S2. The $X$. citri subsp. citri wild-type strain and mutants were cultured at $28^{\circ} \mathrm{C}$ in NB (Difco Laboratories, Detroit), on nutrient agar (NA) plates, in a XVM2 medium (Wengelnik et al. 1996), on M9 minimal medium plates (Chong 2001), or in a peptone sucrose medium. The E. coli strains were grown in LB medium at $37^{\circ} \mathrm{C}$. When required, antibiotics were used at the following concentrations: rifamycin at $50 \mu \mathrm{g} / \mathrm{ml}$, kanamycin (Kan) at $50 \mu \mathrm{g} / \mathrm{ml}$, Amp at $100 \mu \mathrm{g} / \mathrm{ml}$, gentamicin $(\mathrm{Gm})$ at $5 \mu \mathrm{g} / \mathrm{ml}$, and spectinomycin (Spec) at $50 \mu \mathrm{g} / \mathrm{ml}$.

\section{Generation of the vrpA mutant and complementation strains.}

The vrpA gene was deleted by integrating the suicide vector pOK1 into chromosomal DNA via double-crossover homologous recombination. Briefly, the 810-bp left border fragment and the 896-bp right border fragment were amplified using two pairs of primers, 3049 LB-F and 3049 LB-R, respectively, as well as 3049RB-F and 3049RB-R, with wild-type 306 genomic DNA as a template; they were then linked through double-joint PCR. The flanking fragment was digested by ApaI and $\mathrm{XbaI}$ and ligated with a similarly digested pOK1 vector to form pOK1-
VrpA. The resulting construct was transformed into Xac306 through electroporation. The transformed cells were selected on NA plates supplemented with Spec. The positive colonies were then replicated on NA plates supplemented with $5 \%$ (wt/vol) sucrose for negative selection. The sucrose-sensitive colonies were selected, cultured overnight, and dilution-plated on NA containing 5\% (wt/vol) sucrose to select colonies with a second crossover event. The resulting vrpA mutant was confirmed through PCR and Southern blotting. The vrpA gene mutations in $X$. campestris pv. campestris ATCC 33913 and X. campestris pv. vesicatoria strains $85^{*}$ were generated using a similar method with the suicide vector pNPTS138.

To complement through insertion, the entire ORF of the $v r p A$ gene with the 480-bp upstream sequence was amplified and cloned into the plasmid pPM7 $g$ to generate pPM7 gVrpA. The resulting construct was then integrated into the $X$. citri subsp. citri vrpA mutant chromosome through single-crossover recombination with the $\alpha$-amylase gene via electroporation. The transconjugated cells were selected on NA plates with Kan. The presence of $v r p A$ was verified using PCR. For complementation of ectopic overexpression, the entire ORF of the vrpA gene was amplified and cloned into the pTF53 plasmid to generate pTF53-VrpA. vrpA gene expression is driven by the $\mathrm{P}_{\text {trp }}$ promoter. The resulting plasmid was transferred into the vrpA mutant through electroporation. The transconjugated cells were selected on NA plates with $\mathrm{Gm}$.

\section{Southern blot analysis.}

The genomic DNA samples were isolated from both wildtype 306 and a $v r p A$ mutant using a Wizard genomic DNA purification kit (Promega Corp., Madison, WI, U.S.A.); they were subsequently purified using phenol-chloroform-isoamyl alcohol (25:24:1, vol/vol/vol) and chloroform-isoamyl alcohol $(24: 1, \mathrm{vol} / \mathrm{vol})$ in accordance with a standard molecular biology protocol (Chong 2001). After washing with $70 \%$ (vol/vol) ethanol and drying, the DNA samples were resuspended in RNase- and DNase-free water and then subjected to digestion with PstI. The digested products were loaded on a $0.9 \%$ agarose gel for electrophoresis, and transferred to a positively charged nylon membrane (Roche, Indianapolis, IN, U.S.A.) using standard procedures (Guo et al. 2011). The vrpA gene left-border sequence was used as the hybridization probe (Fig. 1A). Probe labeling, hybridization, and chemiluminescence detection were performed using a digoxigenin-High Prime II DNA labeling and detection starter kit as recommended by the manufacturer (Roche).

\section{Pathogenicity assay in plants and bacterial growth curve assay in vitro and in vivo.}

As described in our previous study (Guo et al. 2011; Li and Wang 2011; Yan and Wang 2012), the pathogenicity assays using grapefruit (Citrus paradise Macf. Duncan) or sweet orange ( $C$. sinensis (L.) Osbeck) were performed in a quarantined greenhouse at the Citrus Research and Education Center, Lake Alfred, FL, U.S.A. The pathogenicity assays using Arabidopsis Col-0 were performed as described (Meyer et al. 2005). Bacteria were grown in planta as described previously (Guo et al. 2011; Li and Wang 2011; Yan and Wang 2012). The in planta growth assay was repeated independently three times with at least three replicates for each time. The data from one representative experiment are presented. For the in vitro growth curves, the bacterial strains were grown overnight in $5 \mathrm{ml}$ of NB supplemented with the appropriate antibiotics. Next, $3 \mathrm{ml}$ of the cell suspensions $\left(\mathrm{OD}_{600}=0.3\right)$ was transferred into 100 $\mathrm{ml}$ flasks containing $30 \mathrm{ml}$ of NB medium or XVM2 medium with the appropriate antibiotics. The cultures were grown at $28^{\circ} \mathrm{C}$ with agitation at $200 \mathrm{rpm}$, and the bacterial population 
$\left(\mathrm{OD}_{600}\right)$ was measured over $48 \mathrm{~h}$ using a spectrophotometer 289 (WPA CO8000 Biowave Cell Density Meter; Biochrom Ltd., Cambridge, U.K.). At least three replicates were included at each time point. The experiments were repeated twice.

\section{Subcellular fractionation assay.}

Fractionation of the $X$. citri subsp. citri vrpA mutants harboring pTF53-VrpA or pTF53-VrpA $\mathrm{AN}_{26}$ was performed as described (Morita et al. 2006), with certain modifications. Briefly, the strains were grown in XVM2 overnight. An 8-ml aliquot of culture was centrifuged for $10 \mathrm{~min}$ at $8,000 \times g$. The $\mathrm{SN}$ was decanted and filtered through a $0.22-\mu \mathrm{m}$, sterilized, low-proteinbinding filter. The protein in the $\mathrm{SN}$ was precipitated by adding $1 \mathrm{ml}$ of cold $40 \%$ (wt/vol) trichloroacetic acid in acetone $\left(-20^{\circ} \mathrm{C}\right)$ to $1 \mathrm{ml}$ of $\mathrm{SN}$. After incubating at $-20^{\circ} \mathrm{C}$ for $4 \mathrm{~h}$, the mixture was centrifuged for $30 \mathrm{~min}$ at $20,000 \times g$ at $4^{\circ} \mathrm{C}$. The pellet was washed twice with $100 \mu \mathrm{l}$ of ice-cold $80 \%$ (vol/vol) acetone in water and dissolved in Laemmli sample buffer, which composed the EC. For the whole-cell fraction, the cells harvested from $10 \mathrm{~min}$ of centrifugation at $8,000 \times g$ were suspended in $100 \mathrm{mM}$ Tris- $\mathrm{HCl}(\mathrm{pH} \mathrm{8.0)}$ with $20 \%$ (wt/vol) sucrose and adjusted to an $\mathrm{OD}_{600}$ of 10 . After adding the same volume of Tris- $\mathrm{HCl}$ with $5 \mathrm{mM}$ EDTA and $20 \mu \mathrm{g}$ of egg lysozyme, the samples were incubated for $30 \mathrm{~min}$ at room temperature. The cells were centrifuged at $10,000 \times g$ for $20 \mathrm{~min}$, and the $\mathrm{SN}$ was the PP. The precipitated pellet (spheroblast) was washed twice with cold phosphate-buffered saline (PBS) and resuspended in Laemmli sample buffer to generate the CM fraction.

\section{PhoA reporter assays.}

The phoA gene fusion assays were performed as described (Ammerman et al. 2008). Briefly, full-length VrpA and a $\operatorname{VrpA}_{\Delta \mathrm{N} 26}$ truncation mutant were amplified through PCR with two pairs of primers, VrpAphoAinF and N26phoAinR as well as N26phoAinF and N26phoAinR, respectively. The amplified fragments were then inserted into an $\mathrm{MfeI}$ - and SacI-digested pJDT1 plasmid using an In-Fusion cloning kit (Clontech, Palo Alto, CA, U.S.A.) to produce an in-frame gene fusion between the PCR product and $p h o A$ gene. The resulting constructs and an empty vector were introduced into $E$. coli JM109 competent cells. The strains were cultured on LB plates supplemented with BCIP (the chromogenic PhoA substrate) at $90 \mu \mathrm{g} / \mathrm{ml}, 75 \mathrm{mM}$ $\mathrm{Na}_{2} \mathrm{HPO}_{4}$ (to repress endogenous phosphatase activity), and Amp at $100 \mu \mathrm{g} / \mathrm{ml}$. Pictures were taken $24 \mathrm{~h}$ postinoculation.

\section{Cya protein translocation assay.}

The Cya fusion protein activity was determined in vivo as described, with modifications (Roden et al. 2004). Briefly, the avrXv4::cya cassette was cut with XhoI and EcoRI from the pMS107 plasmid (a gift from the lab of J. B. Jones) and ligated into pBBRMCS-5, which produced pGM-XC1. The plasmid was then introduced into X. citri subsp. citri 306 (wild type), a $v r p A$ mutant, a $v r p A$ insertion complementary strain, and the $h r c V$ and $h r c N$ mutants. The cultured strains were suspended in $10 \mathrm{mM} \mathrm{MgCl}_{2}$ at an $\mathrm{OD}_{600}$ of 0.3 and then hand infiltrated into Nicotiana benthamiana leaves. A direct cAMP correlation enzyme immunoassay kit (Abcam) was used to process the leaf samples and measure the cAMP concentrations following the manufacturer's instructions. The protein content of each sample was determined using the Bio-Rad protein assay (Bio-Rad).

\section{Secretion assay and protein analysis.}

The type III effector AvrGf1, which induces HR in grapefruit (Rybak et al. 2009), was amplified using the primers GF1Xho-F and GF1Eco-R and ligated into a similarly digested pBBRMCS-5 plasmid, which generated pGM-AvrGF1. For
HrpE, HrpF, and XopN proteins, the entire ORFs were amplified using Q5 High-Fidelity DNA Polymerase (NEB). The fragments were inserted into pTF53 plasmid by In-Fusion cloning technology (Clontech). All constructs were introduced into the $X$. campestris pv. vesicatoria strains $85^{*}$ (wild type) and $85^{*} \Delta v r p A$. Growth of the derivative strains in secretion medium (minimal medium A supplemented with sucrose, casamino acids, bovine serum albumen, and thiamine) and the protein secretion assays were conducted as described (Büttner et al. 2002, 2006). To ensure that no bacterial lysis occurred, an antibody specific for the intracellular protein RNA polymerase was routinely added to the blots.

\section{Y2H assay.}

For the $\mathrm{Y} 2 \mathrm{H}$ assay, the coding region of VrpA without the first 26 amino acids was amplified and inserted into the pGADT7 vector to generate an AD fusion. For the GAL4 DNA-binding (BD) fusion proteins, the following regions were amplified and inserted into the pGBKT7 vector: full-length HrpB1; HrcJ, 27-207; HrcC, 33-370; full-length HrpB2; and HrpD5, 39-312. Both the bait and prey were co-transformed into the yeast strain Y2HGold using the LiAc method. The auto-activation test was performed with pGADT7-VrpA alone in Y2HGold strain. The protein interactions were assayed as described (Matchmaker Gold Yeast Two-Hybrid System User Manual; Clontech).

\section{GST pull-down assay.}

E. coli cells expressing GST or GST fusion proteins were washed in PBS and suspended into CelLytic B Cell Lysis Reagent (Sigma-Aldrich) to generate the cell lysates. After centrifugation, the cell lysates were incubated with glutathione agarose beads in accordance with the GST Protein Interaction Pull-Down Kit instructions (Thermo Scientific). The beads were washed to remove the unbound proteins and incubated with $E$. coli cell lysates expressing $\operatorname{VrpA}_{\Delta \mathrm{N} 26}$ for 1 to $2 \mathrm{~h}$ at $4^{\circ} \mathrm{C}$. After washing four times, the beads were eluted with 10 $\mathrm{mM}$ glutathione, and the eluates were collected and immunoblotted using anti-His and anti-GST antibodies in accordance with the instructions.

\section{RNA extraction and QRT-PCR.}

The $X$. citri subsp. citri strains were cultured in an NB or $\mathrm{XVM} 2$ medium at $28^{\circ} \mathrm{C}$ with shaking at $200 \mathrm{rpm}$, and $10-\mathrm{ml}$ samples of the bacterial cells were collected at 7,14, and $19 \mathrm{~h}$ after inoculation. The RNA was immediately stabilized by mixing the culture with two volumes of RNAprotect Bacteria Reagent (Qiagen, Valencia, CA, U.S.A.) and extracted using the RNeasy Mini Kit (Qiagen). Contaminated genomic DNA was removed through treatment with a TURBO DNA-free kit (Ambion, Austin, TX, U.S.A.). The RNA concentration was determined using a NanoDrop ND-1000 spectrophotometer (NanoDrop Technologies, Wilmington, DE, U.S.A.) and adjusted to $75 \mathrm{ng} / \mathrm{ml}$. The RNA obtained was subjected to a one-step QRT-PCR assay using a QuantiTect SYBR green RTPCR kit (Qiagen) on a 7500 fast real-time PCR system (Applied Biosystems, Foster City, CA, U.S.A.). The gyrA gene was used as an endogenous control. The relative fold change in target gene expression was calculated using the formula $2^{-\Delta \Delta C T}$ (Livak and Schmittgen 2001). RNA extraction from plants was performed using the RNeasy plant mini kit (Qiagen), and the $C s L O B 1$ expression level was determined as described above.

\section{ACKNOWLEDGMENTS}

We thank J. B. Jones, Department of Plant Pathology, University of Florida, for the gift of the pMS107 plasmid for the cya fusion assay; M. 
B. Mudgett, Department of Biology, Stanford University, for the gift of $X$. campestris pv. vesicatoria $85^{*}$ and $85^{*} \Delta h r c V$ mutant strains; and M. S. Rahman and A. Azad, University of Maryland School of Medicine, for the gift of the pJDT plasmid for the PhoA assay.

\section{LITERATURE CITED}

Ammerman, N. C., Rahman, M. S., and Azad, A. F. 2008. Characterization of Sec-translocon-dependent extracytoplasmic proteins of Rickettsia typhi. J. Bacteriol. 190, 6234-6242.

Amy, M., Velge, P., Senocq, D., Bottreau, E., Mompart, F., and VirlogeuxPayant, I. 2004. Identification of a new Salmonella enterica serovar Enteritidis locus involved in cell invasion and in the colonisation of chicks. Res. Microbiol. 155:543-552.

Astua-Monge, G., Freitas-Astua, J., Bacocina, G., Roncoletta, J., Carvalho, S. A., and Machado, M. A. 2005. Expression profiling of virulence and pathogenicity genes of Xanthomonas axonopodis pv. citri. J. Bacteriol. 187:1201-1205.

Baker, C. J., and Orlandi, E. W. 1995. Active oxygen in plant pathogenesis. Annu. Rev. Phytopathol. 33:299-321.

Bliska, J. B., Wang, X., Viboud, G. I., and Brodsky, I. E. 2013. Modulation of innate immune responses by Yersinia type III secretion system translocators and effectors. Cell Microbiol. 15:1622-1631.

Bogdanove, A. J., Beer, S. V., Bonas, U., Boucher, C. A., Collmer, A., Coplin, D. L., Cornelis, G. R., Huang, H. C., Hutcheson, S. W., Panopoulos, N. J., and Van Gijsegem, F. 1996. Unified nomenclature for broadly conserved hrp genes of phytopathogenic bacteria. Mol. Microbiol. 20:681-683.

Bolwell, G. P., Bindschedler, L. V., Blee, K. A., Butt, V. S., Davies, D. R., Gardner, S. L., Gerrish, C., and Minibayeva, F. 2002. The apoplastic oxidative burst in response to biotic stress in plants, a three-component system. J. Exp. Bot. 53:1367-1376.

Bronstein, P. A., Marrichi, M., Cartinhour, S., Schneider, D. J., and DeLisa, M. P. 2005. Identification of a twin-arginine translocation system in Pseudomonas syringae pv. tomato DC3000 and its contribution to pathogenicity and fitness. J. Bacteriol. 187:8450-8461.

Bruser, T., Yano, T., Brune, D. C., and Daldal, F. 2003. Membrane targeting of a folded and cofactor-containing protein. Eur. J. Biochem. 270:1211-1221

Bulmer, D. M., Kharraz, L., Grant, A. J., Dean, P., Morgan, F. J., Karavolos, M. H., Doble, A. C., McGhie, E. J., Koronakis, V., Daniel, R. A., Mastroeni, P., and Khan, C. M. 2012. The bacterial cytoskeleton modulates motility, type 3 secretion, and colonization in Salmonella. PLoS Pathog. 8:e1002500.

Büttner, D. 2012. Protein export according to schedule: Architecture, assembly, and regulation of Type III Secretion Systems from plant- and animal-pathogenic bacteria. Microbiol. Mol. Biol. Rev. 76:262-310.

Büttner, D., and He, S. Y. 2009. Type III protein secretion in plant-pathogenic bacteria. Plant Physiol. 150:1656-1664

Büttner, D., Nennstiel, D., Klusener, B., and Bonas, U. 2002. Functional analysis of $\mathrm{HrpF}$, a putative type III translocon protein from Xanthomonas campestris pv. vesicatoria. J. Bacteriol. 184:2389-2398.

Büttner, D., Lorenz, C., Weber, E., and Bonas, U. 2006. Targeting of two effector protein classes to the type III secretion system by a HpaC- and HpaB-dependent protein complex from Xanthomonas campestris pv. vesicatoria. Mol. Microbiol. 59:513-527.

Chong, L. 2001. Molecular cloning-A laboratory manual, 3rd ed. Science 292:446-446.

Diepold, A., and Wagner, S. 2014. Assembly of the bacterial type III secretion machinery. FEMS (Fed. Cur. Microbiol. Soc.) Microbiol. Rev. 38:802-822.

Fardini, Y., Chettab, K., Grepinet, O., Rochereau, S., Trotereau, J., Harvey, P., Amy, M., Bottreau, E., Bumstead, N., Barrow, P. A., and VirlogeuxPayant, I. 2007. The YfgL lipoprotein is essential for type III secretion system expression and virulence of Salmonella enterica serovar Enteritidis. Infect Immun. 75:358-370.

Feng, F., and Zhou, J. M. 2012. Plant-bacterial pathogen interactions mediated by type III effectors. Curr. Opin. Plant Biol. 15:469-476.

Fenselau, S., and Bonas, U. 1995. Sequence and expression analysis of the hrpB pathogenicity operon of Xanthomonas campestris pv. vesicatoria which encodes eight proteins with similarity to components of the Hrp, Ysc, Spa, and Fli secretion systems. Mol. Plant-Microbe Interact. 8:845-854.

Fujii, T., Cheung, M., Blanco, A., Kato, T., Blocker, A. J., and Namba, K. 2012. Structure of a type III secretion needle at 7-angstrom resolution provides insights into its assembly and signaling mechanisms. Proc. Natl. Acad. Sci. U.S.A. 109:4461-4466.

Garcia-Gomez, E., Espinosa, N., de la Mora, J., Dreyfus, G., and GonzalezPedrajo, B. 2011. The muramidase EtgA from enteropathogenic Esche- richia coli is required for efficient type III secretion. Microbiology 157:1145-1160

Gottwald, T., and Riley, T. 2005. The effect of hurricanes and tropical storms on long distance spread of citrus canker. Phytopathology 95:S36-S36.

Guo, Y. P., Figueiredo, F., Jones, J., and Wang, N. 2011. HrpG and HrpX play global roles in coordinating different virulence traits of Xanthomonas axonopodis pv. citri. Mol. Plant-Microbe Interact. 24:649-661.

Hammond-Kosack, K. E., and Jones, J. D. G. 1996. Resistance gene-dependent plant defense responses. Plant Cell 8:1773-1791.

Hartmann, N., Schulz, S., Lorenz, C., Fraas, S., Hause, G., and Büttner, D. 2012. Characterization of $\mathrm{HrpB} 2$ from Xanthomonas campestris py. vesicatoria identifies protein regions that are essential for type III secretion pilus formation. Microbiology 158:1334-1349.

Hausner, J., Hartmann, N., Lorenz, C., and Büttner, D. 2013. The periplasmic HrpB1 protein from Xanthomonas spp. binds to peptidoglycan and to components of the type III secretion system. Appl. Environ. Microbiol. 79:6312-6324

Hu, Y., Zhang, J. L., Jia, H. G., Sosso, D., Li, T., Frommer, W. B., Yang, B., White, F. F., Wang, N. A., and Jones, J. B. 2014. Lateral organ boundaries 1 is a disease susceptibility gene for citrus bacterial canker disease. Proc. Natl. Acad. Sci. U.S.A. 111:E521-E529.

Jalan, N., Kumar, D., Andrade, M.O., Yu, F., Jones, J. B., Graham, J. H., White, F. F., Setubal, J. C., and Wang, N. 2013. Comparative genomic and transcriptome analyses of pathotypes of Xanthomonas citri subsp. citri provide insights into mechanisms of bacterial virulence and host range. BMC Genomics 14:551.

Kawamoto, A., Morimoto, Y. V., Miyata, T., Minamino, T., Hughes, K. T., Kato, T., and Namba, K. 2013. Common and distinct structural features of Salmonella injectisome and flagellar basal body. Sci. Rep. 3:3369.

Kogenaru, S., Qing, Y., Guo, Y., and Wang, N. 2012. RNA-seq and microarray complement each other in transcriptome profiling. BMC Genomics 13:629.

Kumar, N., Ebel, R. C., and Roberts, P. D. 2011. $\mathrm{H}_{2} \mathrm{O}_{2}$ metabolism during sweet orange (Citrus sinensis L. Osb.) .Hamlin. Xanthomonas axonopodis pv. citri interaction. Sci. Hortic. 128:465-472.

Lee, C., Lee, S. M., Mukhopadhyay, P., Kim, S. J., Lee, S. C., Ahn, W. S., Yu, M. H., Storz, G., and Ryu, S. E. 2004. Redox regulation of OxyR requires specific disulfide bond formation involving a rapid kinetic reaction path. Nat. Struct. Mol. Biol. 11:1179-1185.

Levine, A., Tenhaken, R., Dixon, R., and Lamb, C. 1994. $\mathrm{H}_{2} \mathrm{O}_{2}$ from the oxidative burst orchestrates the plant hypersensitive disease resistance response. Cell 79:583-593.

Li, J. Y., and Wang, N. A. 2011. The wxacO gene of Xanthomonas citri ssp. citri encodes a protein with a role in lipopolysaccharide biosynthesis, biofilm formation, stress tolerance and virulence. Mol. Plant Pathol. 12:381-396.

Li, R. F., Lu, G. T., Li, L., Su, H. Z., Feng, G. F., Chen, Y., He, Y. Q., Jiang, B. L., Tang, D. J., and Tang, J. L. 2013. Identification of a putative cognate sensor kinase for the two-component response regulator HrpG, a key regulator controlling the expression of the hrp genes in Xanthomonas campestris pv. campestris. Environ. Microbiol. 16:2053-2071

Lin, D., Rao, C. V., and Slauch, J. M. 2008. The Salmonella SPI1 type three secretion system responds to periplasmic disulfide bond status via the flagellar apparatus and the RcsCDB system. J. Bacteriol. 190:87-97.

Livak, K. J., and Schmittgen, T. D. 2001. Analysis of relative gene expression data using real-time quantitative PCR and the 2(T)(-delta delta C) method. Methods 25:402-408.

Lohou, D., Lonjon, F., Genin, S., and Vailleau, F. 2013. Type III chaperones \& Co in bacterial plant pathogens: A set of specialized bodyguard mediating effector delivery. Front. Plant Sci. 4:435.

Loquet, A., Sgourakis, N. G., Gupta, R., Giller, K., Riedel, D., Goosmann, C., Griesinger, C., Kolbe, M., Baker, D., Becker, S., and Lange, A. 2012. Atomic model of the type III secretion system needle. Nature 486:276.

Majdalani, N., and Gottesman, S. 2005. The Rcs phosphorelay: A complex signal transduction system. Annu. Rev. Microbiol. 59:379-405.

Marlovits, T. C., Kubori, T., Sukhan, A., Thomas, D. R., Galan, J. E., and Unger, V. M. 2004. Structural insights into the assembly of the type III secretion needle complex. Science 306:1040-1042.

Matsui, D., Oikawa, T., Arakawa, N., Osumi, S., Lausberg, F., Stabler, N. Freudl, R., and Eggeling, L. 2009. A periplasmic, pyridoxal-5.-phosphate-dependent amino acid racemase in Pseudomonas taetrolens. Appl. Microbiol. Biot. 83:1045-1054.

Merdanovic, M., Clausen, T., Kaiser, M., Huber, R., and Ehrmann, M. 2011. Protein quality control in the bacterial periplasm. Annu. Rev. Microbiol. 65:149-168.

Meyer, D., Lauber, E., Roby, D., Arlat, M., and Kroj, T. 2005. Optimization of pathogenicity assays to study the Arabidopsis thaliana-Xanthomonas campestris pv. campestris pathosystem. Mol. Plant Pathol. 6:327-333. 
Morita, Y. S., Sena, C. B. C., Waller, R. F., Kurokawa, K., Sernee, M. F. Nakatani, F., Haites, R. E., Billman-Jacobe, H., McConville, M. J., Maeda, Y., and Kinoshita, T. 2006. PimE is a polyprenol-phosphatemannose-dependent mannosyltransferase that transfers the fifth mannose of phosphatidylinositol mannoside in mycobacteria. J. Biol. Chem. 281:25143-25155.

Ramos, P. L., Van Trappen, S., Thompson, F. L., Rocha, R. C. S., Barbosa, H. R., De Vos, P., and Moreira, C. A. 2011. Screening for endophytic nitrogen-fixing bacteria in Brazilian sugar cane varieties used in organic farming and description of Stenotrophomonas pavanii sp. nov. Int. J. Syst. Evol. Microbiol. 61:926-931.

Roden, J., Eardley, L., Hotson, A., Cao, Y. Y., and Mudgett, M. B. 2004. Characterization of the Xanthomonas AvrXv4 effector, a SUMO protease translocated into plant cells. Mol. Plant-Microbe Interact. 17:633643.

Rossier, O., Wengelnik, K., Hahn, K., and Bonas, U. 1999. The Xanthomonas Hrp type III system secretes proteins from plant and mammalian bacterial pathogens. Proc. Natl. Acad. Sci. U.S.A. 96:9368-9373.

Ryan, R. P., Vorholter, F. J., Potnis, N., Jones, J. B., Van Sluys, M. A., Bogdanove, A. J., and Dow, J. M. 2011. Pathogenomics of Xanthomonas: Understanding bacterium-plant interactions. Nat. Rev. Microbiol. 9:344-355.

Rybak, M., Minsavage, G. V., Stall, R. E., and Jones, J. B. 2009. Identification of Xanthomonas citri ssp. citri host specificity genes in a heterologous expression host. Mol. Plant Pathol. 10:249-262.

Schlegel, S., Rujas, E., Ytterberg, A. J., Zubarev, R. A., Luirink, J., and de Gier, J. W. 2013. Optimizing heterologous protein production in the periplasm of E. coli by regulating gene expression levels. Microb. Cell. Fact. 12:24.

Seo, J., and Darwin, A. J. 2013. The Pseudomonas aeruginosa periplasmic protease CtpA can affect systems that impact its ability to mount both acute and chronic infections. Infect. Immun. 81:4561-4570.

Simpson, A. J. G., Reinach, F. C., Arruda, P., Abreu, F. A., Acencio, M., Alvarenga, R., Alves, L. M. C., Araya, J. E., Baia, G. S., Baptista, C. S., Barros, M. H., Bonaccorsi, E. D., Bordin, S., Bové, J. M., Briones, M. R., Bueno, M. R., Camargo, A. A., Camargo, L. E., Carraro, D. M., Carrer, H., Colauto, N. B., Colombo, C., Costa, F. F., Costa, M. C., Costa-Neto, C. M., Coutinho, L. L., Cristofani, M., Dias-Neto, E., Docena, C., El-Dorry, H., Facincani, A. P., Ferreira, A. J., Ferreira, V. C., Ferro, J. A., Fraga, J. S., França, S. C., Franco, M. C., Frohme, M., Furlan, L. R., Garnier, M., Goldman, G. H., Goldman, M. H., Gomes, S. L., Gruber, A., Ho, P. L., Hoheisel, J. D., Junqueira, M. L., Kemper, E. L., Kitajima, J. P., Krieger, J. E., Kuramae, E. E., Laigret, F., Lambais, M. R., Leite, L. C., Lemos, E. G., Lemos, M. V., Lopes, S. A., Lopes, C. R., Machado, J. A., Machado, M. A., Madeira, A. M., Madeira, H. M., Marino, C. L., Marques, M. V., Martins, E. A., Martins, E. M., Matsukuma, A. Y., Menck, C. F., Miracca, E. C., Miyaki, C. Y., Monteriro-Vitorello, C. B., Moon, D. H., Nagai, M. A., Nascimento, A. L., Netto, L. E., Nhani, A., Jr., Nobrega, F. G., Nunes, L. R., Oliveira, M. A., de Oliveira, M. C., de Oliveira, R. C., Palmieri, D. A., Paris, A., Peixoto, B. R., Pereira, G. A., Pereira, H. A., Jr., Pesquero, J. B., Quaggio, R. B., Roberto, P. G., Rodrigues, V., de M. Rosa, A. J., de Rosa, V. E. Jr., de Sá, R. G., Santelli, R. V., Sawasaki, H. E., da Silva, A. C., da Silva, A. M., da Silva, F. R., da Silva, W. A. Jr., da Silveira, J. F., Silvestri, M. L., Siqueira, W. J., de Souza, A. A., de Souza, A. P. Terenzi, M. F., Truffi, D., Tsai, S. M., Tsuhako, M. H., Vallada, H., Van Sluys, M. A., Verjovski-Almeida, S., Vettore, A. L., Zago, M. A., Zatz,
M., Meidanis, J., and Setubal, J. C. 2000. The genome sequence of the plant pathogen Xylella fastidiosa. Nature 406:151-157.

Sory, M. P., Boland, A., Lambermont, I., and Cornelis, G. R. 1995. Identification of the YopE and YopH domains required for secretion and internalization into the cytosol of macrophages, using the cyaA gene fusion approach. Proc. Natl. Acad. Sci. U.S.A. 92:11998-12002.

Soscia, C., Hachani, A., Bernadac, A., Filloux, A., and Bleves, S. 2007. Cross talk between type III secretion and flagellar assembly systems in Pseudomonas aeruginosa. J. Bacteriol. 189:3124-3132.

Spreter, T., Yip, C. K., Sanowar, S., Andre, I., Kimbrough, T. G., Vuckovic, M., Pfuetzner, R. A., Deng, W. Y., Yu, A. C., Finlay, B. B., Baker, D., Miller, S. I., and Strynadka, N. C. J. 2009. A conserved structural motif mediates formation of the periplasmic rings in the type III secretion system. Nat. Struct. Mol. Biol. 16:468-476.

Sukhan, A., Kubori, T., Wilson, J., and Galan, J. E. 2001. Genetic analysis of assembly of the Salmonella enterica serovar Typhimurium type III secretion-associated needle complex. J. Bacteriol. 183:1159-1167.

Tampakaki, A. P., Skandalis, N., Gazi, A. D., Bastaki, M. N., Sarris, P. F., Charova, S. N., Kokkinidis, M., and Panopoulos, N. J. 2010. Playing the "Harp": Evolution of our understanding of hrp/hrc Genes. Annu. Rev. Phytopathol. 48:347-370.

Vicente, J. G., and Holub, E. B. 2013. Xanthomonas campestris pv. campestris (cause of black rot of crucifers) in the genomic era is still a worldwide threat to brassica crops. Mol. Plant Pathol. 14:2-18.

Wagner, S., Sorg, I., Degiacomi, M., Journet, L., Dal Peraro, M., and Cornelis, G. R. 2009. The helical content of the YscP molecular ruler determines the length of the Yersinia injectisome. Mol. Microbiol. 71:692-701.

Wengelnik, K., Marie, C., Russel, M., and Bonas, U. 1996. Expression and localization of HrpA1, a protein of Xanthomonas campestris pv. vesicatoria essential for pathogenicity and induction of the hypersensitive reaction. J. Bacteriol. 178:1061-1069.

Wengelnik, K., Rossier, O., and Bonas, U. 1999. Mutations in the regulatory gene hrpG of Xanthomonas campestris pv. vesicatoria result in constitutive expression of all hrp genes. J. Bacteriol. 181:6828-6831.

Weon, H. Y., Kim, B. Y., Hong, S. B., Jeon, Y. A., Kwon, S. W., Go, S. J., and Koo, B. S. 2007. Rhodanobacter ginsengisoli sp. nov. and Rhodanobacter terrae sp. nov., isolated from soil cultivated with Korean ginseng. Int. J. Syst. Evol. Microbiol. 57:2810-2813.

Wojtaszek, P. 1997. Oxidative burst, an early plant response to pathogen infection. Biochem. J. 322:681-692.

Yan, Q., and Wang, N. 2012. High-Throughput screening and analysis of genes of Xanthomonas citri subsp. citri involved in citrus canker symptom development. Mol. Plant-Microbe Interact. 25:69-84.

Yoo, S. H., Weon, H. Y., Kim, B. Y., Kim, J. H., Baek, Y. K., Kwon, S. W., Go, S. J., and Stackebrandt, E. 2007. Pseudoxanthomonas yeongjuensis sp. nov., isolated from soil cultivated with Korean ginseng. Int. J. Syst. Evol. Microbiol. 57:646-649.

Zahrl, D., Wagner, M., Bischof, K., Bayer, M., Zavecz, B., Beranek, A., Ruckenstuhl, C., Zarfel, G. E., and Koraimann, G. 2005. Peptidoglycan degradation by specialized lytic transglycosylases associated with type III and type IV secretion systems. Microbiology 151:3455-3467.

\section{AUTHOR-RECOMMENDED INTERNET RESOURCE}

SignalP 4.1 server: www.cbs.dtu.dk/services/SignalP 